\title{
Foreldelse når et krav trekkes fra et tvisteløsningsorgan
}

Av professor dr. juris Olav Torvund

Når et krav bringes inn for en domstol eller et annet tvisteløsningsorgan, avbrytes

foreldelsesfristen etter foreldelsesloven (fe.) $\S \S 15,15$ a eller 16. Så lenge kravet er til

behandling, blir det ikke foreldet. Får man medhold i sitt krav, løper en ny foreldelsesfrist fra avgjørelsen. Blir avgjørelsen at man ikke har noe krav, da har man ikke noe krav og foreldelsesspørsmålet blir uinteressant.

Hvis behandling ender uten noen form for realitetsavgjørelse, f.eks. fordi saken avvises, har man etter fe. $\S 22$ nr. 1 en tilleggsfrist på inntil et år. Foreldelse inntrer tidligst et år etter at behandlingen ble avsluttet. Dette gjelder ikke dersom det skyldtes et forsettlig forhold fra kreditors side at saken ikke fikk en realitetsavgjørelse. Da løper ingen tilleggsfrist.

Går vi til foreldelseslovens forarbeider, synes det klart at man mente at forsettsvurderingen knyttet seg til saksanlegget. Hvis et krav går mot foreldelse, skal man ikke kunne få en forlengelse ved å anlegge et søksmål som åpenbart må avvises. I Ot.prp. nr. 38 (1977-78) s. 75 sies om dette:

«Departementet er imidlertid kommet til at bestemmelsen bør beholdes som en sikkerhetsventil. Dersom det er åpenbart at kravet må avvises, er det ikke rimelig at fordringshaveren skal oppnå en tilleggsfrist ved påtale. [sic. Må forstås som søksmål.]»

Ved revisjon av tvisteloven i 2007 ble det brakt betydelig uklarhet inn i dette. Tvistelovutvalget ville sikre at man ikke skulle risikere umiddelbar foreldelse dersom en sak blir trukket fra behandling i forliksrådet, og tilsvarende hvis et sivilt krav ble trukket fra en straffesak. Utvalget mente at fe. § $22 \mathrm{nr} .1$ ikke var tilstrekkelig, da det kunne hevdes at det å trekke en sak fra et tvisteløsningsorgan er en forsettlig handling. De skriver om dette i NOU 2001: 32B s. 875:

«Unntaket i foreldelsesloven $\S 22$ om at det er forsettlig at saken ender uten realitetsavgjørelse, er lite velegnet for denne typen situasjoner. Når klageren trekker saken fra behandling i forliksrådet for i stedet å fremme den for tingretten, vil dette som regel måtte karakteriseres som forsettlig. Det vil være såkalt hensiktsforsett.»

Utvalget foreslo derfor en bestemmelse i § 20-3, som senere ble vedtatt som tvisteloven $\S 18$ 3. Dennes annet ledd lyder:

«(2) Når foreldelse er avbrutt ved forliksklage, opphører denne virkningen dersom stevning, eller eventuelt forliksklage, ikke er sendt til retten innen ett år fra forliksrådet innstilte behandlingen av saken.»

Det er ingen tvil om at utvalget med dette mente å sikre at et krav ikke blir foreldet om saken trekkes. Utvalget sier i NOU 2001: 32B s. 875:

«Men det virker lite rimelig at klageren, når han etter et bevisst valg etter hvert finner ut at han snarere vil ha saken fremmet for tingretten, ikke skal nyte godt av den samme tilleggsfristen. Det er mulig man ved en tolkning av forsettskriteriet i foreldelsesloven §22 kunne funnet frem til akseptable løsninger her. En bedre løsning er nok å la være å knytte tilleggsfristen på ett år til noe forsettskriterium i disse tilfellene. Tvistemålsutvalget har ikke grunnlag for å foreslå en opphevelse 
av det generelle forsettsunntaket i foreldelsesloven $\S 22 \mathrm{nr}$. 1. Det fremstår da som den beste løsningen at man beholder en spesialregulering i tvisteloven av disse situasjonene.»

Og videre, på s. 880:

«I lovutkastet er det foreslått at klageren skal ha fri adgang til å trekke saken fra forliksrådet, uten at kravet med det oppgis. (...) Når Tvistemålsutvalget likevel har funnet grunn til å videreføre en bestemmelse om dette i tvisteloven, er det fordi foreldelsesloven §22 ikke gir noen tilleggsfrist på ett år når det er 'forsettlig' at saken ender uten rettslig avgjørelse. For å unngå misforståelser, og at forsettsbegrepet må legges på strekk når klageren trekker en sak fra behandling i forliksrådet, bør det være en eksplisitt bestemmelse som regulerer denne siden ved foreldelsesspørsmålet i tvisteloven.»

Departementet fremmet et forslag som i sin ordlyd var identisk med utvalgets forslag. Men departementets merknader til forslaget henger ikke sammen med det som ble foreslått og senere vedtatt. Det heter i Ot.prp. nr. 51 (2004-2005) s. 432-433:

«Annet ledd kommer bare til anvendelse når forliksrådet innstiller behandlingen av saken. Når forliksklagen blir trukket, vil saken bli hevet, jf §19-1 annet ledd bokstav b. Da vil spørsmålet om foreldelse bare bli regulert av lov 18. mai 1979 nr. 18 om foreldelse av fordringer $\$ 22 \mathrm{nr} .1$ første punktum. Forsettskravet i den bestemmelsen vil normalt lede til at virkningen av påtale ved forliksklage vil bortfalle straks klagen trekkes tilbake.»

Så langt jeg kan se, er dette alt som sies om spørsmålet i proposisjonen. Hvorfor man har valgt å fremme utvalgets forslag, men med motsatt forståelse av forholdet til $f e$. $\S 22$, er ikke drøftet eller begrunnet. Dermed blir ikke bare rekkevidden av fe. § 22 uklar, men også tvl. § 18-3.

Departementet brakte ytterligere forvirring inn i dette da fe. § $22 \mathrm{nr} .1$ i 2007 fikk et nytt siste punktum i forbindelse med en endring i tvisteloven. Dette lyder:

«Når fornærmede trekker sin begjæring om å få pådømt krav i straffesak, varer virkningen av rettidig påtale etter § 15 i ett år fra fornærmede meddelte domstolen eller påtalemyndigheten om tilbaketrekkingen.»

Den handlingen er like forsettlig som å trekke en sak fra et annet tvisteløsningsorgan. I forarbeidene til denne endringen, Ot.prp. nr. 74 (2005-2006), finnes det ingen begrunnelse for denne tilføyelsen, og følgelig heller ikke en begrunnelse for å velge en annen løsning enn det som ifølge departementets tidligere uttalelser er hovedregelen i fe. § 22. Også dette bygger på tvistelovutvalgets innstilling. Utvalgets forslag var at samme regel skulle gjelde både når sak trekkes fra forliksrådet, og når sivilt krav trekkes fra en straffesak.

Jeg antar at man må følge departementets uttalelse i Ot.prp. nr. 51 (2004-2005) s. 432$433 \mathrm{om}$ at virkningen av at et krav blir trukket fra forliksrådsbehandling. Derimot er det usikkert om man får en tilleggsfrist på et år for å bringe saken inn for domstolene dersom saken blir trukket fra et annet tvisteløsningsorgan.

Hvis en part har brakt en sak inn for et tvisteløsningsorgan, og så kommer til at dette betyr en ekstra runde i et organ som kanskje er uegnet til å håndtere saken, og man mener at saken uansett vil ende i domstolene, løper man en risiko dersom den normale foreldelsesfristen vil ha løpt ut på det tidspunkt saken trekkes. Som rådgiver må man være 
klar over at det i det minste medfører en risiko om saken trekkes. Om man allerede har havnet i denne situasjonen, vil det nok kunne være et prosedabelt standpunkt å påstå at fe. § 22 nr. 1 ikke omfatter denne form for forsett. Man vil f.eks. kunne anføre at forarbeidene til endringene i tvisteloven er etterarbeider til foreldelsesloven, og at de som sådan har begrenset vekt. Men sikkert vil det ikke være.

Dersom saken er til behandling i et tvisteløsningsorgan som ikke har litispendensvirkning, vil man kunne komme rundt problemet ved å ta ut stevning og dermed avbryte foreldelsen på nytt, før saken trekkes fra tvisteløsningsorganet. Hvis tvisteløsningsorganet har litispendensvirkning, vil den muligheten være stengt. Hvis man velger en forsiktig tilnærming, vil man være henvist til å avvente en avgjørelse i tvisteløsningsorganet før saken bringes videre - med det tidstap og de kostnader dette medfører.

Jeg har møtt dette spørsmålet i praksis i to ulike situasjoner. I den første var det taktiske vurderinger rundt spørsmålet om å avslutte behandling i et tvisteløsningsorgan, for heller å bringe saken inn for domstolene - og hvor det var et spørsmål om vi kunne anbefale dette, noe vi da kom til at vi ikke kunne.

I det andre tilfellet hadde en saksøker i en voldgiftssak, etter anmodning fra voldgiftsrettens formann, valgt å trekke et erstatningskrav. Voldgiftsrettens formann mente at kravet var for dårlig opplyst, slik det sto i den saken. Erstatningskravet kom senere opp i en ny voldgiftssak. Vi representerte da saksøkte, og påsto foreldelse, blant annet med den begrunnelse at saksøker forsettlig hadde trukket kravet fra den første voldgiftsbehandlingen. Voldgiftsretten kom til at kravet var foreldet, men på et annet grunnlag - og kunne dermed la være å ta stilling til konsekvensene av å trekke kravet.

Det ville ikke ha vært rimelig om konsekvensen av å følge oppfordringen fra rettens formann i en slik sak skulle bli at kravet er tapt ved foreldelse.

Tvistelovutvalget skrev i NOU 2001: 32B s. 875, som er sitert mer utførlig ovenfor:

«Men det virker lite rimelig at klageren, når han etter et bevisst valg etter hvert finner ut at han snarere vil ha saken fremmet for tingretten, ikke skal nyte godt av den samme tilleggsfristen.»

Utvalget skriver om forliksrådet. Men argumentasjonen treffer like godt når det gjelder andre tvisteløsningsorganer, slik at løsningen da bør være den samme. 